\title{
TRACKING THE LOCATIONS OF HINDU-BUDDHIST ARCHAEOLOGICAL REMAINS IN MAGELANG REGION BASED ON ROD 1914 AND GIS APPROACH
}

\section{PELACAKAN LOKASI TINGGALAN HINDU-BUDDHA BERDASARKAN ROD 1914 DAN PENDEKATAN SIG DI WILAYAH MAGELANG}

\author{
Ari Mukti Wardoyo Adi \\ Program Studi Arkeologi, Universitas Jambi \\ ariwardoyo@unja.ac.id
}

\begin{abstract}
ABSTRAK
Pulau Jawa pernah menjadi pusat perkembangan kebudayaan bercorak HinduBuddha sekitar abad ke-4 hingga ke-15 M. Tinggalan arkeologi dari periode ini sangat tinggi, baik berupa candi, petirtaan, maupun tinggalan lepas seperti arca, yoni, lingga, dan sejenisnya. Inventarisasi tinggalan tersebut sudah dilakukan secara sistematis sejak masa pemerintah Hindia Belanda melalui Dinas Purbakala (Oudheidkundig Dienst). Sayangnya sebagian besar tinggalan arkeologi tersebut sekarang tidak lagi diketahui secara tepat lokasi. Ada yang kemudian ditemukan secara tidak sengaja pada saat kegiatan pembangunan ataupun pengerjaan lahan pertanian. Penelitian ini berupaya untuk melacak ulang lokasi tinggalan arkeologi Hindu-Buddha yang pernah dilaporkan oleh Dinas Purbakala Belanda di Wilayah Magelang. Proses pelacakan dilakukan menggunakan pendekatan Sistem Informasi Geografis. Hasilnya berupa peta sebaran lokasi tinggalan arkeologi Hindu-Buddha. Peta ini menunjukkan bahwa di Wilayah Magelang, pada periode Hindia-Belanda, mengandung tinggalan arkeologi HinduBuddha yang padat. Hasil penelitian ini diharapkan dapat dimanfaatkan untuk kegiatan survei, reinventarisasi, hingga upaya pelindungan dan pelestariannya.
\end{abstract}

Kata Kunci: arkeologi Hindu-Buddha; ROD 1914; SIG; toponim; Magelang

\section{ABSTRACT}

Java was once the center of Hindu and Buddhist culture around the $4^{\text {th }}$ until the $15^{\text {th }}$ century AD. The number of archaeological remains from this period is infinite, both monumental remains such as temples and petirtaan (water shrines/ temple), and other remains such as yoni, linga, and statues. These remains are registered systematically by the Dutch East Indies government through its Archaeological Service (Oudheidkundig Dienst). unfortunately, most of them cannot be identified for their exact present locations. Some of the remains were later discovered unexpectedly at the time of construction or agricultural work activities. Therefore, this study seeks to investigate the locations of archaeological remains as reported by the Dutch Archaeological Service in the region of Magelang using the Geographic Information System (GIS) approach. This study suggests that, during the period of the Dutch East Indies, Magelang region has a very high density of HinduBuddhist archaeological remains. The result of this study can be used for further surveys, re-inventory, as well as protection and preservation efforts.

Keywords: Hindu-Buddhist remains; ROD 1914; GIS; toponym; Magelang

Article Submitted : : :15-12-2019

Article Accepted : : :08-04-2020 


\section{INTRODUCTION}

The Hindu-Buddhist period in Indonesia is marked by the inclusion of Indian cultural influence on various aspects. The buildings and objects of worship set in Hinduism and Buddhism are material culture left from that period. The Hindu-Buddhist archaeological remains are found in many western regions of Indonesia, especially Java, Sumatra, and Kalimantan. The island of Java was even the location of the central government of several kingdoms, ranging from Tarumanegara around the 4th century AD, Mataram around the 8th century AD to the 10th century AD, to Majapahit in the 15th century AD (Cœdès, 1968, pp. 8196; Hägerdal, 2016; Tichelman \& Tichelman, 2011).

Magelang is one region with a high density of Hindu-Buddhist archaeological remains on the island of Java. The remains of places of worship for Hinduism and Buddhism such as temples, petirtaan (ritual bathing pool), and holy sites are often found in this region. This assumption is based on the survey and inventory that have been conducted since the Dutch East Indies period. In addition to the survey and inventory reports, several recent studies also indicate that this region has an important role in the Hindu-Buddhist period (Adi, 2012, 2016; Atmosudiro, 2001; Degroot, 2009; Tjahjono, 2000; Utomo, 1981).

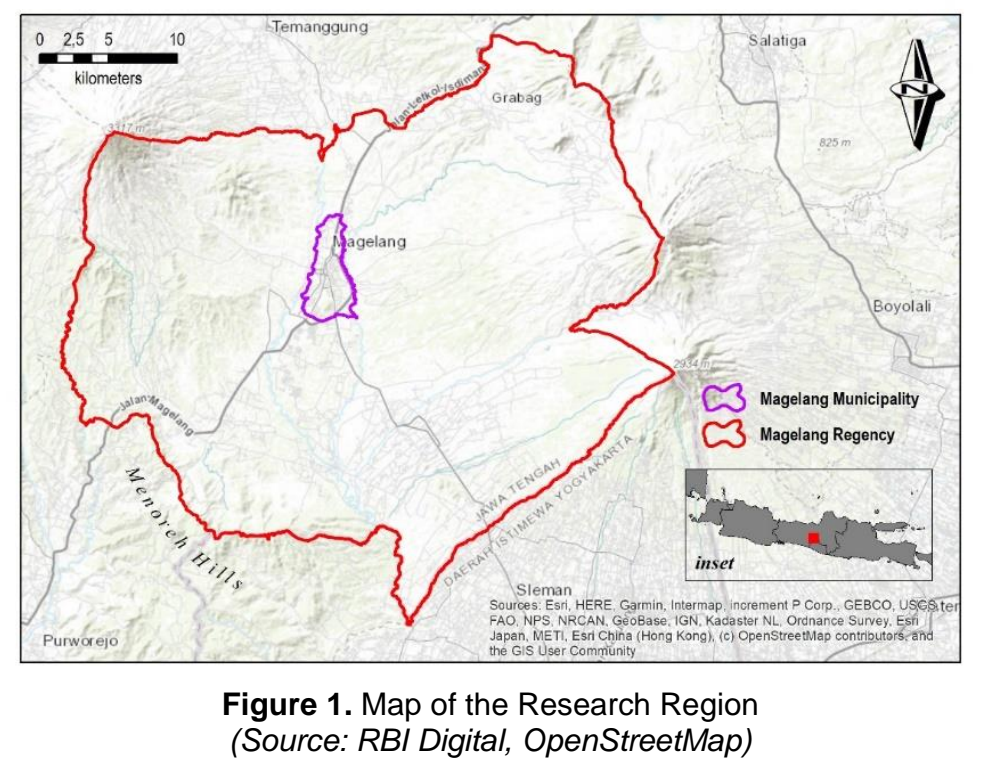

The region of Magelang currently consists of Magelang Regency and Magelang Municipality (Figure 1). It is located in the central part of Java Island and is in a strategic position because it connects two very important provincial capitals, i.e. the Special Region of Yogyakarta and Semarang (Central Java Province). In Hindu-Buddhist period, this region is believed to be the main access connecting the north coast of Java (ranging from Semarang to Pekalongan) with the administrative center of the Ancient Mataram Kingdom located on the Borobudur-Prambanan axis through Wonosobo and Temanggung (Darmosoetopo, 2003; Degroot, 2009; Degroot \& Klokke, 2010; Noerwidi, 2007). This strategic location is supported by a high level of land fertility due to the 
volcanism process of the surrounding volcanoes. In addition, water in this region is also abundant, both surface water sources such as springs and rivers and groundwater (Murtianto \& Arifin, 1999; Yuliyanto \& Sudibyakto, 2012).

Before the Independence of Indonesia, the Hindu-Buddhist archaeological report in Magelang can be found in several documents published by both Bataviaasch Genootschap and Oudheidkundigen Dienst (Groot, 2009; Soekmono, 2002). After independence, the archaeological reports are generally published by the Indonesian Archaeological Service. However, after 1975, the Archaeological Service was split into two institutions, namely the Directorate of History and Archaeology and the Center of Archaeology and National Heritage (Soekmono, 2002). The two institutions then changed their names several times without changing their functions. After the separation, the archaeological inventory report then boils down to two types. The first is the inventory reports concerning preservation and restoration, which are mostly published by institutions engaged in the field of conservation, and the second is the reports concerning academic research and development, which are published by institutions engaged in research.

The survey and inventory activities of Hindu-Buddhist archaeological remains in Magelang since the Dutch East Indies Government have not made the remains well preserved. Most of the remains are actually not well maintained. This is because there is no further attention from the relevant institutions. Frequently, the Hindu-Buddhist archaeological findings, which are rediscovered by the local community, are considered as new discovery whose news is appalling. These 'rediscoveries' commonly occur accidentally when people are constructing a building or processing agricultural land. Some of the latest Hindu-Buddhist archaeological discoveries in Magelang include:

1. The discovery of a petirtaan (bathing structure) named Mantingan in Salam Subdistrict (Susanto, 2019);

2. The discovery of temple ruins in Ngandong Hamlet, Dukun Subdistrict (Ramadhan, 2017);

3. The discovery of temple ruins and some Hindu worship objects in Gendungan Hamlet, Dukun Subdistrict (Purnama, 2016);

4. The discovery of temple ruins, yoni, linga, and statues in Sangubanyu Hamlet, Bandongan Subdistrict (Fitriana, 2015); and

5. The discovery of yoni and linga in Wonokoso Hamlet, Pakis Subdistrict, and the discovery of giant linga in Tampir Wetan Village, Candimulyo Subdistrict (Hartono, 2013).

The neglected Hindu-Buddhist archaeological remains and the lack of public knowledge about the importance of such remains make the situation getting worse. Another threat comes from the massive regional development as part of the government's main program. Moreover, the rate of change in land use from green open land to constructed land in Magelang is also getting higher. This is the impact of regional economic growth based on optimizing local potential to increase community income (Winata, 2018).

One effort that can be done to minimize the threat and the level of damage of Hindu-Buddhist archaeological remains in Magelang is to conduct a complete 
inventory. This inventory program can range from the identification of the locations of archaeological remains and potential remains to mapping the distribution. The process certainly is time-consuming and costly if it is directly performed in the field. Therefore, this study offers an effort to make an inventory using an approach that can shorten the time and save costs. This effort is a model to track down the locations of Hindu-Buddhist archaeological remains as reported by the Dutch East Indies Government using a geographic information system and toponym analysis.

The final result of this study is a model for creating a database and map of toponym distribution that has implications for the Hindu-Buddhist archaeological remains in Magelang in the Dutch East Indies period. The database and map can be used as a basis for the re-inventory and reference of field surveys to rediscover Hindu-Buddhist Buddhist archaeological remains in Magelang. The offered model can also be employed to make a re-inventory of Hindu-Buddhist archaeological remains in Indonesia. The results of the inventory can be used to formulate the strategies for future research and preservation of archaeological remains.

The archaeological heritage tracking model with a toponym approach is performed by using the geographic information system (GIS) device. GIS has been widely used in archaeology, especially those related to spatial dimensions. GIS began to be used by archaeology along with the development of computer technology in the late 1980s (Scianna \& Villa, 2011; Wheatley \& Gillings, 2010). GIS has a very important function in various stages of academic research such as analysis, classification, calculation, combination, modeling, and visual representation of archaeological data (Yuwono, 2007). GIS is a useful device for combining geographic data with a database management system that aims to store and save important information contained in archaeological data. Some countries in Europe and America since the 1990s have even developed cultural resource management systems based on GIS (Verhagen, 2007, p. 17).

Studies on toponyms in relation to Hindu-Buddhist archaeological remains in spatial dimensions have been widely conducted. However, the existing studies focus more on discussing toponyms mentioned in the Hindu-Buddhist period only, especially those that originate from inscriptions. For example, Kusen (1991) conducted a study of the toponyms contained in the inscriptions found around Prambanan area. The toponyms are then linked to the toponyms that are still used around the current Prambanan area. The results of his study show that there are several toponyms in the inscriptions that are still used as the names of the hamlets and villages in Prambanan and surrounding areas, even though with different pronunciation and writing (Kusen, 1991).

Wulan Resiyani (2010) examined the toponyms found in the IX-X century AD inscriptions around Temanggung Regency. The used method is almost the same as Kusen's study (1991), i.e. matching toponyms that are still used in Temanggung Regency today. However, her study adds data from the folklore that develops in the community regarding the origin of place names. The results of her study suggest that there are still many toponyms in Temanggung Regency that have similarities to the names mentioned in the inscriptions. The names also have a background story that is still trusted by the community (Resiyani, 2010). 
Agus Aris Munandar (2016) made eight toponym assessment models in archaeology. The focus of toponym analysis is the toponym found in inscriptions and manuscripts from the Hindu-Buddhist period. All the models link three aspects, i.e. the explanation of the meaning of a place name, the location of the current toponym, and the role of the toponym in contemporaneous culture. The toponyms mentioned in the written source in the Hindu-Buddhist period and the current locations are believed to have a role in the past so the Hindu-Buddhist archaeological remains are likely to be found there. Munandar further stated that generally, the discovery of Hindu-Buddhist archaeological remains takes place between the late 1800s to the early 1900s. The names of the locations of HinduBuddhist archaeological remains have survived since they are discovered until the present, even though there have been quite a lot of changing administrative regions (Munandar, 2016).

The study conducted by Kusen (1991), Resiyani (2010), and Munandar (2016) focused more on the toponym found in the inscription. On the other hand, the studies focus more on investigating aspects of spatial and inter-regional relations during the Hindu-Buddhist era. A toponym study concerning the location name of the Hindu-Buddhist archaeological remains in the report of the Dutch East Indies Government has never been conducted so far. Therefore, this study seeks to investigate the report of Hindu-Buddhist archaeological remains to create a tracking model using the toponym approach. The focus of this model is to identify the toponym location in the Dutch East Indies inventory report as well as the potential archaeological remains.

\section{METHODS}

Magelang was used as an initial example in this study model because, aside from being thought to have the potential for massive Hindu-Buddhist archaeological remains, studies in this region was also very less. The toponym that is still used in Magelang is also relatively the same as the toponym in the Dutch East Indies period. The comparison of the Indonesia topographical map published in 2001 with the Dutch East Indies topographical map published in 1915 in Magelang (Figure 2) shows that the majority of the names of hamlets and villages have not changed. For example, the 2001 topographical map writes Japan village Rejosari village, Klopo hamlet while the 1915 topographical map writes Djapan, Redjosari, and Klopo. The land-use patterns on the two maps also do not change much, except for a number of residential areas developing outwards. Therefore, it can be assumed that the locations mentioned in the Dutch East Indies Government report can still be traced down.

The report on the Hindu-Buddhist archaeological inventory published by the Dutch East Indies Government used in this study was the 1914 Rapporten van den Oudheidkundigen Dienst in Nederlandsch-Indie: Inventaris der Hindoe-oudheden or ROD 1914. It is a series of Hindu-Buddhist archaeological inventory reports published between 1913-1940 (Krom, 1914). ROD 1914 was chosen because only this report is the most complete one mentioning the locations of Hindu-Buddhist archaeological remains in Magelang. The reports on archaeological remains in this 
region are mentioned in ROC 1911 (Knebbel, 1911), but they are not as complete as those found in ROD 1914. In addition, the publishing year of ROD 1914 is closer to the topographical map published by Topographische Inrichting in 1915, so that it would be easier in tracking the toponym mentioned in the report. Please note that ROD 1914 has no maps, but only a list of locations and the archaeological remains on the locations. The region of Magelang in ROD 1914 is called Afdeeling Magelang which is divided into seven districts namely: District Magelang, District Bandongan, District Tegalredja, District Grabag, District Moentilan, District Salam, and District Salaman. ROD 1914 also includes references to previous reports that mentioned archaeological remains in Magelang.
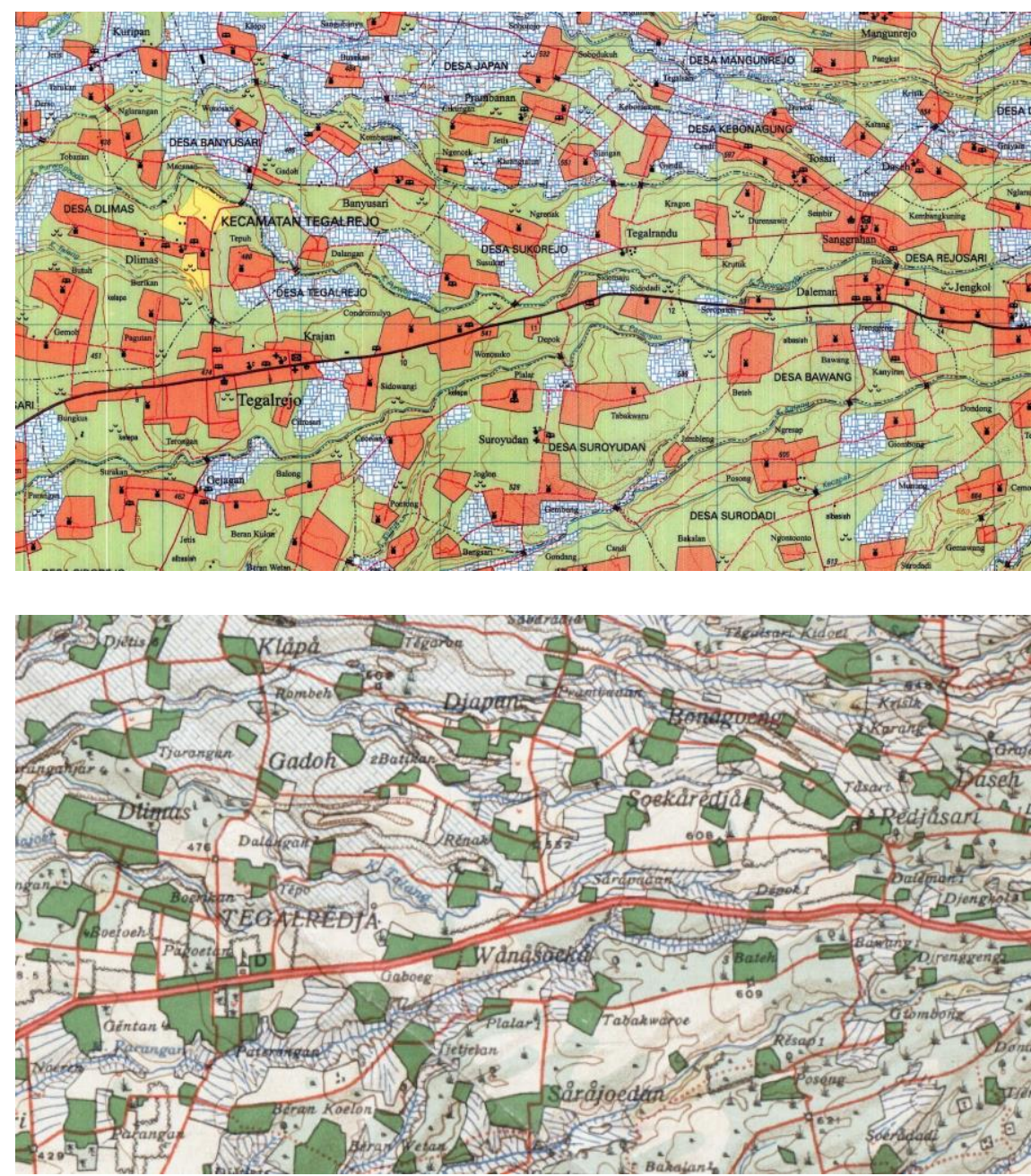

Figure 2. The Comparison of toponyms between the 2001 Indonesia topographic map (above) and the map published by Topograpische Inrichting in 1915 (below)

(Source: Digital Indonesia Topographic Map pages 1408-521 of Tegalrejo published by BAKOSURTANAL 2001 scale 1: 25,000 and Magelang Map en Omstreken published by Topograpische Inrichting 1915 scale 1: 50,000)

A list of Hindu-Buddhist archaeological remains in Magelang as reported in ROD 1914 lies on pages 211 to 277. The Hindu-Buddhist archaeological remains as recorded in ROD 1914 can be divided into three categories based on the types of 
the findings or conditions at the reporting time, i.e. the structure and building, the building ruins, and fragmentary remains. The structure and building category includes all the information of the so-called fundamenten (foundation/structure), tempel (temple), tjandi (temple), as well as rijen steenen or rijen kalisteenen (stone or river stone structure). This category is believed to be archaeological remains in the form of temples or Hindu-Buddhist religious buildings that are still intact in their basic structure. The category of building ruins includes all information reported in terms of overblijfselen (ruins), tjandi-steenen (temple stones), and groote aantal tempelsteenen or tempelbaksteenen (a large number of temple stones/bricks). This category is believed to be the ruins of worship buildings which are still concentrated in one particular location and allegedly still have an intact structure in it. The category of fragmentary remains includes all information reported in terms of beeld; beelden; beeldje (figure/statue), steenen beeld (stone statue), yoni, lingga, nandi, as well as the names of deities both in Hinduism and Buddhism.

The method used to track down the toponyms of ROD 1914 can be seen more clearly in Figure 3. All the toponyms listed in ROD 1914 were inputted in the database and sorted by administrative units in the Dutch East Indies period, namely the districts. Furthermore, all the toponyms in the database were identified by locating their names with the current toponyms obtained from the digital Indonesia topographical map. The data from the digital map included toponym point data and administrative data at the village/ward and subdistrict levels in a polygon form. The toponym equivalency tracking is performed using the query feature in the ArcGIS application. This is done because the use of query in some GIS applications is very helpful for selecting data based on attributes and spatial locations (Scianna \& Villa, 2011).

The toponym tracking was also performed by using a topographical map from the Dutch East Indies period. This was needed to track the names of the locations which have no equivalent to the present toponyms. The used topographical map was a map published by Topographische Inrichting in 1915. The process was relatively simple, i.e. by superimposing the 1915 map on the digital Indonesia topographical map through georeferencing. After that, a toponym equivalency tracking was done manually on the old map.

The toponym in ROD 1914 which has an equivalent to the toponym on the digital Indonesia topographical map and the 1915 map was determined by the location coordinates. As a note, the location coordinates resulting from this process were toponym coordinates which were reported to have potential archaeological remains, not the coordinates of the site. The toponym equivalency process as intended above was also filtered based on the area of each district. The district administrative unit has the same level as the current sub-district. The toponym equivalency with the district area was done to avoid mistakes in determining the coordinates of locations that have the same name between districts. For example, the toponym Tjandi was found in almost all districts. Until now, almost every location in Magelang which has Hindu-Buddhist archaeological remains is named candi, either for the administrative name or place name only so the query process generated a very large number of candi words. The toponym of a place is always associated with the existence of physical features in the place, for example, flora, 
fauna, historical events, names of figures, and geographical conditions (Mashadi \& Zuharnen, 2014; Munandar, 2016).

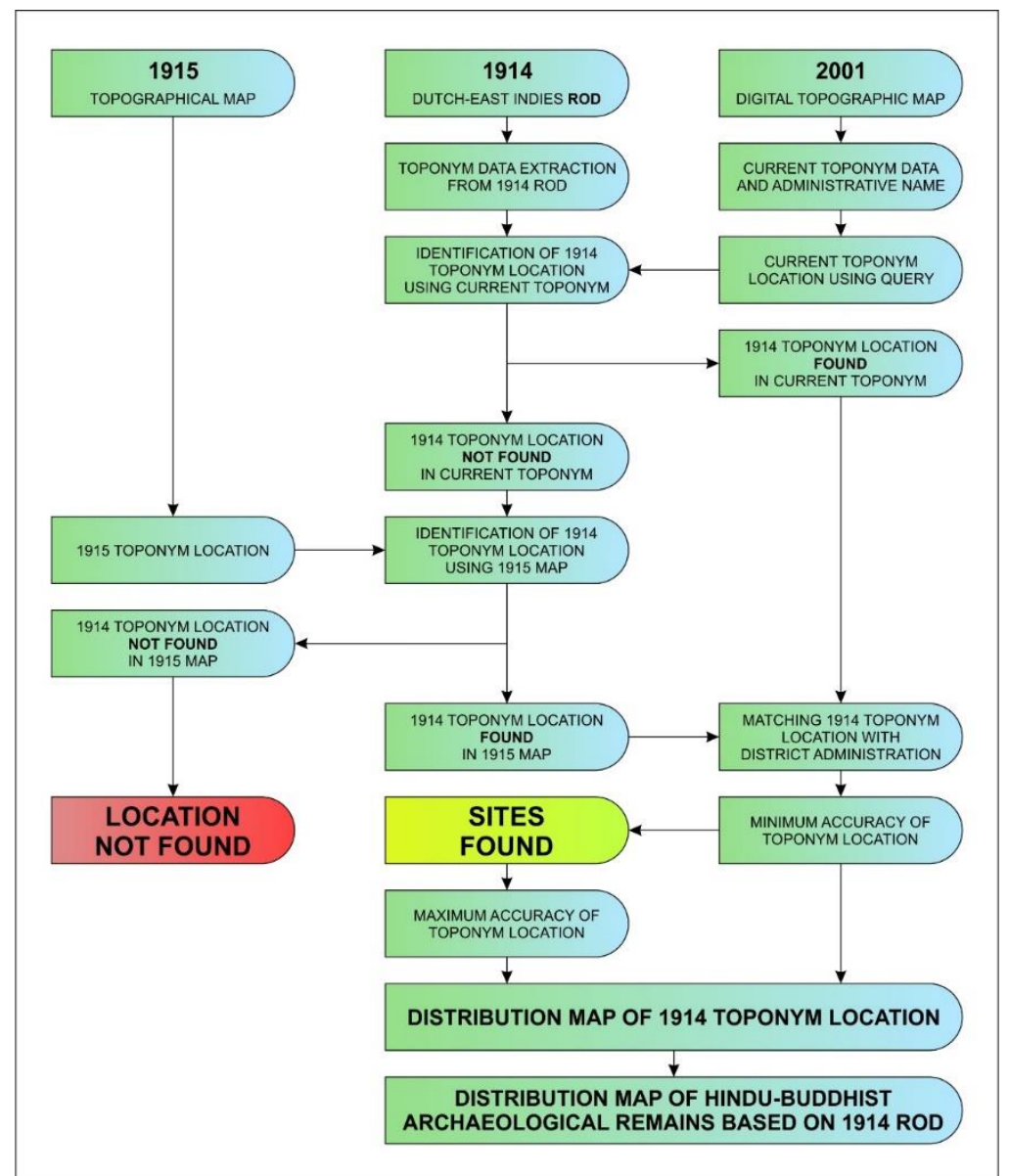

Figure 3. Model of Hindu-Buddhist Archaeological Remains Tracking in ROD 1914 (Source: Ari Mukti Wardoyo Adi))

\section{RESEARCH RESULTS}

ROD 1914 contains 219 names of Hindu-Buddhist archaeological sites scattered in seven districts in Magelang. These location names are under inventory numbers 679 to 897 and only 216 location names can be estimated as sites. Three names that cannot be categorized as site locations include the preservation locations of objects found from the sites, such as Magelang Museum, Resident House, and Wedana House.

Most of the locations of the Hindu-Buddhist archaeological remains listed in ROD 1914 have not been rediscovered at the present. Nevertheless, the coordinates of the locations can still be mapped. Almost all of the location names mentioned in ROD 1914 can still be found today or can be traced through ancient maps. These locations are only estimates plotted through the query and overlay analysis on the maps so the accuracy is low (minimum). Not all locations of the Hindu-Buddhist archaeological remains can be determined because there are several location names that cannot be traced through current or old maps like the map published 
by Topographical Inrichting. Some of the rediscovered Hindu - Buddhist archaeological sites can be plotted on a map with higher accuracy (maximum). The rediscovery of these sites are generally made through archaeological research and surveys, both by the author and by related agencies such as the Central Java Cultural Heritage Conservation Center and Yogyakarta Archaeology Center. Of the 216 archaeological sites reported, only the locations of 204 sites can be traced (Figure 4).

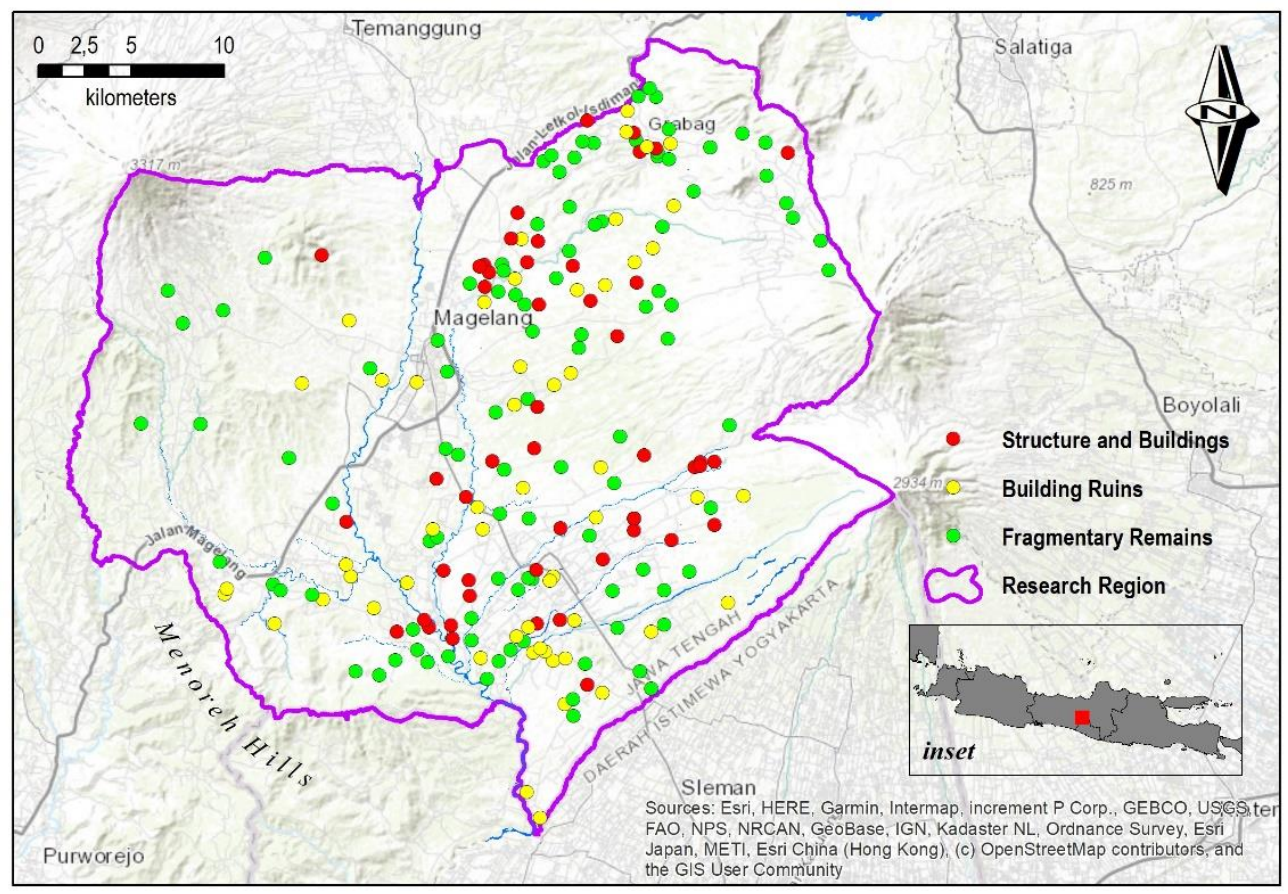

Figure 4. The Distribution of Hindu-Buddhist archeological remains based on ROD 1914 (Source: ROD 1914, OpenStreetMap, Digital Indonesia Topographical Map processed by Ari Mukti Wardoyo Adi)

Based on the analysis results, there are 50 location toponyms of HinduBuddhist archaeological that contain the temple finding both in the form of intact buildings and structures when reported. One toponym cannot be identified with the current toponym or in the ancient map. These findings imply the massive temple buildings in the region of Magelang during the Hindu-Buddhist period. In addition, the conditions are still relatively intact when surveyed by the Dutch Archaeological Service. Some names of Hindu-Buddhist archaeological remains that are included in the structure and building category can be seen in Table 1.

Table 1. List of the names of structure and building locations in ROD 1914 and the

\begin{tabular}{lllllcc}
\multicolumn{9}{c}{ possible current locations } \\
\hline No & $\begin{array}{l}\text { Location (ROD } \\
\mathbf{1 9 1 4})\end{array}$ & $\begin{array}{l}\text { Current } \\
\text { Hamlet }\end{array}$ & $\begin{array}{l}\text { Current } \\
\text { Village }\end{array}$ & $\begin{array}{l}\text { Current } \\
\text { Subdistrict }\end{array}$ & \multicolumn{2}{c}{ Coodinates $^{*}$} \\
\hline $\mathbf{1}$ & Kledokan & Legokan & Danurejo & Mertoyudan & 414309 & $\mathbf{Y}^{*}$ \\
\hline $\mathbf{2}$ & Selagriya & Selogriyo & $\begin{array}{l}\text { Kembangku } \\
\text { ning }\end{array}$ & Windusari & 408139 & 9179210 \\
\hline
\end{tabular}




\begin{tabular}{|c|c|c|c|c|c|c|}
\hline \multirow[t]{2}{*}{ No } & \multirow{2}{*}{$\begin{array}{l}\text { Location (ROD } \\
\text { 1914) }\end{array}$} & \multirow{2}{*}{$\begin{array}{l}\text { Current } \\
\text { Hamlet }\end{array}$} & \multirow{2}{*}{$\begin{array}{l}\text { Current } \\
\text { Village }\end{array}$} & \multirow{2}{*}{$\begin{array}{l}\text { Current } \\
\text { Subdistrict }\end{array}$} & \multicolumn{2}{|c|}{ Coodinates* } \\
\hline & & & & & $\mathbf{X}^{*}$ & $\mathbf{Y}^{*}$ \\
\hline 3 & Batoe Gana & Gunung Gono & Banyubiru & Dukun & 424932 & 9165027 \\
\hline 4 & Gijombong & Giyombong & Surodadi & Candimulyo & 424039 & 9174837 \\
\hline 5 & Gadoh & Gaduh & Banyusari & Tegalrejo & 419835 & 9176539 \\
\hline 6 & Gana & Gono & Gejagan & Pakis & 425089 & 9177712 \\
\hline 7 & Tjandi & Candi & Kebonagung & Tegalrejo & 422611 & 9176739 \\
\hline 8 & Kretek & Beji & Tampirkulon & Candimulyo & 417319 & 9168120 \\
\hline 9 & Bolonglor & Bolong Lor & Tegalsari & Candimulyo & 419578 & 9168824 \\
\hline 10 & Kembaran & Kembaran & Kembaran & Candimulyo & 419734 & 9171030 \\
\hline 11 & Nglangon & Plumbon II & Grabag & Grabag & 424937 & 9185783 \\
\hline 12 & Tjandi Panas & Candiumbul & Kartoharjo & Grabag & 422426 & 9186426 \\
\hline 13 & Poentingan & Puntingan & Grabag & Grabag & 425266 & 9184760 \\
\hline 14 & Kaponan & Kaponan & Grabag & Grabag & 426115 & 9184931 \\
\hline 15 & Bengkoeng & Bengkung & Candiretno & Secang & 416899 & 9178683 \\
\hline 16 & Tjetohan & Cetokan & Candiretno & Secang & 417141 & 9178274 \\
\hline 17 & Tjandiredja & Candiretno & Candiretno & Secang & 416643 & 9178592 \\
\hline 18 & Setan & Bandungan & Setan & Secang & 416925 & 9177507 \\
\hline 19 & Pirikan & Pirikan & Pirikan & Secang & 419202 & 9178835 \\
\hline 20 & Poetjang & $\begin{array}{l}\text { Pucang } \\
\text { Gunung }\end{array}$ & Pucang & Secang & 418323 & 9180082 \\
\hline 21 & Tjandi & Candi & Sidomulyo & Secang & 419763 & 9179939 \\
\hline 22 & Kalangan & Kalangan & Candisari & Secang & 418674 & 9181477 \\
\hline 23 & Tjandi Renteng & Candi Renting & Pandean & Ngablak & 433205 & 9184716 \\
\hline 24 & Lebak & Dakawu & Lebak & Grabag & 421652 & 9178628 \\
\hline 25 & Ketaron & Ketoran & $\begin{array}{l}\text { Tamanagun } \\
\mathrm{g}\end{array}$ & Muntilan & 419684 & 9162266 \\
\hline 26 & Wates & Kwayuhan & Wates & Dukun & 426958 & 9163893 \\
\hline 27 & Tjandi & Candigelo & Sengi & Dukun & 424947 & 9164402 \\
\hline 28 & Goenoeng Gana & Gunung Gono & Banyubiru & Dukun & 424947 & 9165050 \\
\hline 29 & Geblok & unknown & unknown & unknown & - & - \\
\hline 30 & Koewilet & Kuwilet & Ketunggeng & Dukun & 423271 & 9162834 \\
\hline 31 & $\begin{array}{l}\text { Kalibening } \\
\text { doewoer }\end{array}$ & Kalibening & Kalibening & Dukun & 429247 & 9164677 \\
\hline 32 & Seketi & Babadan & Butuh & Sawangan & 425479 & 9168430 \\
\hline 33 & $\begin{array}{l}\text { Tjandi } \\
\text { Loemboeng }\end{array}$ & Candi & Krogowanan & Sawangan & 428179 & 9167808 \\
\hline 34 & Tjandi Pendem & Candi & Sengi & Dukun & 428516 & 9168070 \\
\hline 35 & Tjandi Asoe & Candi & Sengi & Dukun & 428495 & 9167875 \\
\hline 36 & Tjandi & Candi & Ngadipuro & Dukun & 429258 & 9168100 \\
\hline 37 & Goenoeng Lemah & $\begin{array}{l}\text { Gunung } \\
\text { Lemah }\end{array}$ & Gondowangi & Sawangan & 420971 & 9164521 \\
\hline
\end{tabular}




\begin{tabular}{lllllll}
\hline No & $\begin{array}{l}\text { Location (ROD } \\
\text { 1914) }\end{array}$ & $\begin{array}{l}\text { Current } \\
\text { Hamlet }\end{array}$ & $\begin{array}{l}\text { Current } \\
\text { Village }\end{array}$ & $\begin{array}{l}\text { Current } \\
\text { Subdistrict }\end{array}$ & \multicolumn{2}{c}{ Coodinates $^{*}$} \\
\hline $\mathbf{3 8}$ & Gedongan & Gedongan & Blondo & Mungkid & 415911 & 9166183 \\
$\mathbf{3 9}$ & Ngawen & Ngawen & Ngawen & Muntilan & 419727 & 9159389 \\
$\mathbf{4 0}$ & Ngradjek & Ngrajek & Ngrajek & Mungkid & 416114 & 9160891 \\
$\mathbf{4 1}$ & Rambianak & Rambeanak & Rambeanak & Mungkid & 414698 & 9162240 \\
$\mathbf{4 2}$ & Kendal & Kendal & Rambeanak & Mungkid & 416061 & 9161711 \\
$\mathbf{4 3}$ & Mendoet & Mendut & Mendut & Mungkid & 415089 & 9159303 \\
$\mathbf{4 4}$ & Keparen & Paren & Progowati & Mungkid & 415193 & 9158562 \\
$\mathbf{4 5}$ & Kadiloewih & Gunung Wukir & Tirto & Salam & 422418 & 9156102 \\
\hline $\mathbf{4 6}$ & Goenoeng Sari & Gunung Sari & Gulon & Salam & 420958 & 9159599 \\
$\mathbf{4 7}$ & Bata & Botoh & Sumberarum & Tempuran & 409472 & 9164870 \\
\hline $\mathbf{4 8}$ & Borobudur & Borobudur & Borobudur & Borobudur & 412182 & 9158949 \\
$\mathbf{4 9}$ & Tjandi Pawon & Wanurejo & Wanurejo & Borobudur & 413928 & 9159175 \\
$\mathbf{5 0}$ & Tjandi Banon & Brojonalan & Borobudur & Borobudur & 413666 & 9159573 \\
\hline & & Source: $R O D D$ 1914 and the author's data processing by. &
\end{tabular}

In addition to the temple buildings which are still relatively intact in their structure and foundation, ROD 1914 also reports 57 toponyms containing the ruins of the temple buildings. Three toponyms cannot be identified for the current equivalent of their names on the 1915 Dutch map so the locations cannot be determined. The ruins referred to in ROD 1914 are strongly believed to still have a structure in it. Nevertheless, since most are found in residential areas, it is believed that the structure and parts of the building have been deformed and transformed. The deformation, in this case, is damage to the structure or the original form of the building, while transformation is a change in the aspect of the location. The discovery locations are generally reported to be in residential areas (gehucht, dorpje) and graves (kerkhof, begraafplaats). The development of settlements, agricultural land use, and the construction of public facilities such as tombs and places of worship are thought to be the main factors of the deformation and transformation of the archaeological remains. ROD 1914 also reported on the displacement of archaeological remains such as the ruins of temple rocks. For example, some temple stones in Gijombong are reported to be moved to Tembelang-Lor (Krom, 1914, p. 221). The names of Hindu-Buddhist archaeological remains that are categorized as building ruins can be seen in Table 2 .

Tabel 2. List of the location names of building ruins in ROD 1914 and the possible current locations

\begin{tabular}{|c|c|c|c|c|c|c|}
\hline \multirow[t]{2}{*}{ No } & \multirow{2}{*}{$\begin{array}{l}\text { Location (ROD } \\
\text { 1914) }\end{array}$} & \multirow{2}{*}{$\begin{array}{l}\text { Current } \\
\text { Hamlet }\end{array}$} & \multirow{2}{*}{$\begin{array}{l}\text { Current } \\
\text { Village }\end{array}$} & \multirow{2}{*}{$\begin{array}{l}\text { Current } \\
\text { Subdistrict }\end{array}$} & \multicolumn{2}{|c|}{ Coodinates $^{*}$} \\
\hline & & & & & $\mathbf{X}^{\star}$ & $Y^{\star}$ \\
\hline 1 & Dejangan & Deyangan & Deyangan & Mertoyudan & 412748 & 9161590 \\
\hline 2 & Plaosan & Plaosan & Donorojo & Mertoyudan & 414134 & 9164474 \\
\hline
\end{tabular}




\begin{tabular}{|c|c|c|c|c|c|c|}
\hline \multirow[t]{2}{*}{ No } & \multirow{2}{*}{$\begin{array}{l}\text { Location (ROD } \\
\text { 1914) }\end{array}$} & \multirow{2}{*}{$\begin{array}{l}\text { Current } \\
\text { Hamlet }\end{array}$} & \multirow{2}{*}{$\begin{array}{l}\text { Current } \\
\text { Village }\end{array}$} & \multirow{2}{*}{$\begin{array}{l}\text { Current } \\
\text { Subdistrict }\end{array}$} & \multicolumn{2}{|c|}{ Coodinates* $^{\star}$} \\
\hline & & & & & $X^{*}$ & $Y^{*}$ \\
\hline 3 & Bajeman II & Bayeman & Kemirirejo & $\begin{array}{l}\text { Magelang } \\
\text { Selatan }\end{array}$ & 413252 & 9172369 \\
\hline 4 & $\begin{array}{l}\text { Tjandi } \\
\text { Goenoeng }\end{array}$ & Candi Gunung & Banyuwangi & Bandongan & 411389 & 9172465 \\
\hline 5 & Batoe rong & Paren & Ketangi & Kaliangkrik & 407096 & 9172313 \\
\hline 6 & Djangkoengan & Jangkungan & Gandusari & Bandongan & 409608 & 9175674 \\
\hline 7 & Gales & Gales & Sidorejo & Tegalrejo & 418821 & 9173208 \\
\hline 8 & Koripan & Kuripan & Dawung & Tegalrejo & 418525 & 9177915 \\
\hline 9 & Toemboe & Tumbu & Purwodadi & Tegalrejo & 416892 & 9176654 \\
\hline 10 & Sabaradja & Sobodukuh & Japan & Tegalrejo & 421872 & 9177330 \\
\hline 11 & Tegaron & Garon & Mangunrejo & Tegalrejo & 423377 & 9177580 \\
\hline 12 & Sotitjleboengan & Soti & Surojoyo & Candimulyo & 418503 & 9171147 \\
\hline 13 & Ngleses-wetan & Ngleses & Candimulyo & Candimulyo & 420640 & 9172224 \\
\hline 14 & Tembelang lor & $\begin{array}{l}\text { Tembelang } \\
\text { Lor }\end{array}$ & Tembelang & Candimulyo & 421544 & 9172847 \\
\hline 15 & Gejer & Medayu & Sidogede & Grabag & 424587 & 9186951 \\
\hline 16 & Ploembon & Plumbon & Grabag & Grabag & 424521 & 9185817 \\
\hline 17 & Klateron & Kleteran & Kleteran & Grabag & 426891 & 9185194 \\
\hline 18 & Kalangan & Kalangan & Grabag & Grabag & 425627 & 9185027 \\
\hline 19 & Randoekoening & Radukuning & Gondosuli & Muntilan & 422883 & 9165089 \\
\hline 20 & Tembalang & Bener & Sidomulyo & Secang & 418867 & 9180069 \\
\hline 21 & Gegerweroe & Geru & Sugihmas & Grabag & 425943 & 9179574 \\
\hline 22 & Andongsari & Pucungsari & Pucungsari & Grabag & 424969 & 9178831 \\
\hline 23 & Salam & Salam & Salam & Grabag & 423961 & 9181135 \\
\hline 24 & Ngandong & Ngandong & Banaran & Grabag & 427083 & 9181844 \\
\hline 25 & Padan & Padansari & Pucungrejo & Muntilan & 420571 & 9161916 \\
\hline 26 & Growong-kidoel & Growong & Pucungrejo & Muntilan & 420408 & 9161699 \\
\hline 27 & Gondangan & Gondangrejo & Keningar & Dukun & 430816 & 9166234 \\
\hline 28 & Tjandi Soember & Candi & Sumber & Dukun & 428333 & 9166154 \\
\hline 29 & Moengkidan & Mungkidan & Butuh & Sawangan & 423152 & 9167762 \\
\hline 30 & Soetadereppan & unknown & unknown & unknown & - & - \\
\hline 31 & $\begin{array}{l}\text { Sekroewetenga } \\
\mathrm{h}\end{array}$ & Srikuwe & Ambartawang & Mungkid & 416810 & 9164471 \\
\hline 32 & Soedimara & Sudimoro & Gondang & Mungkid & 418980 & 9166694 \\
\hline 33 & Pare & Pare & Blondo & Mungkid & 416510 & 9165636 \\
\hline 34 & Nganten & Nganten & Ngawen & Muntilan & 419261 & 9159182 \\
\hline 35 & Gedjagan & Gejagan & Sriwedari & Muntilan & 418614 & 9158687 \\
\hline 36 & Slokopan koelon & Slokopan & Sokorini & Muntilan & 416683 & 9157525 \\
\hline 37 & Mantingan & Mantingan & Mantingan & Salam & 423231 & 9155661 \\
\hline
\end{tabular}




\begin{tabular}{|c|c|c|c|c|c|c|}
\hline \multirow[t]{2}{*}{ No } & \multirow{2}{*}{$\begin{array}{l}\text { Location (ROD } \\
\text { 1914) }\end{array}$} & \multirow{2}{*}{$\begin{array}{l}\text { Current } \\
\text { Hamlet }\end{array}$} & \multirow{2}{*}{$\begin{array}{l}\text { Current } \\
\text { Village }\end{array}$} & \multirow{2}{*}{$\begin{array}{l}\text { Current } \\
\text { Subdistrict }\end{array}$} & \multicolumn{2}{|c|}{ Coodinates $^{\star}$} \\
\hline & & & & & $\mathbf{X}^{*}$ & $\mathbf{Y}^{*}$ \\
\hline 38 & Tombrep & unknown & unknown & unknown & - & - \\
\hline 39 & Medangan & Medangan & Tersangede & Salam & 420570 & 9157392 \\
\hline 40 & Bobosan & Bobosan & Tersangede & Salam & 421243 & 9157521 \\
\hline 41 & Sirahan & Sirahan & Sirahan & Salam & 419523 & 9157821 \\
\hline 42 & Berokan & Berokan & Sirahan & Salam & 420144 & 9157882 \\
\hline 43 & Tjandi Salakan & Candi Salakan & Sirahan & Salam & 419897 & 9158046 \\
\hline 44 & Djlegong & Jlegong & Gulon & Salam & 421726 & 9159554 \\
\hline 45 & Trasahan & Trasahan & Jamuskauman & Ngluwar & 421213 & 9155047 \\
\hline 46 & Bligo & Bligo & Bligo & Ngluwar & 419164 & 9150329 \\
\hline 47 & Kadjoran Kidoel & Kajoran & Bligo & Ngluwar & 419887 & 9148934 \\
\hline 48 & Kradenan & Kradenan & Kradenan & Srumbung & 425851 & 9158943 \\
\hline 49 & Kemiren II & Kemiren & Kemiren & Srumbung & 429991 & 9160499 \\
\hline 50 & Mlanggen & Mlangen & Menoreh & Salam & 402935 & 9160960 \\
\hline 51 & Lipoersari & Mulyosari & Kalisalak & Salaman & 403045 & 9161259 \\
\hline 52 & Gombong & Gombong & Paripurno & Salaman & 405625 & 9159375 \\
\hline 53 & Bowongan & Bowongan & Ringinanom & Tempuran & 409703 & 9161932 \\
\hline 54 & Tjandi & $\begin{array}{l}\text { Candi } \\
\text { Ringinanom }\end{array}$ & Ringinanom & Tempuran & 409462 & 9162566 \\
\hline 55 & Tegalwangi & Tegalwangi & Tegalarum & Borobudur & 408202 & 9160678 \\
\hline 56 & Kanggan & Kanggan & Wringinputih & Borobudur & 410945 & 9160226 \\
\hline 57 & Krasakkidjan & unknown & unknown & unknown & - & - \\
\hline
\end{tabular}

Magelang is also reported to have fragmentary remains. The region is believed to have 109 locations of fragmentary findings and only 102 locations are identified to be today's equivalent toponyms (see Figure 4). The remains are identified as worship media that are not related to buildings such as statues, linga, and yoni. However, it can be assumed that the remains are the components of temple buildings that were detached or intentionally moved, such as statues or relief statues (beeld, beeldje, steenen beelden), ornament relief (steenen ornament, baksteenen ornament), the head of Kala (monsterkop), statue pedestal (voetstuk), Makara, temple stones (tempelblokken), antefix, and Kemuncak (top stuk, tempeltopstuk). The ROD 1914 also has many terms related to object displacement such as overgebracht, gebracht, gebrachten, and afkomstige. This displacement could be part of a preservation effort or even the desire of officials at that time to collect antique objects. Other remains allegedly not related to worship media such as metal objects, jewelry (bronzen armringen), inscriptions, and household utensils in the form of trays (presenteerbladen), bowls (kommetjes) and containers (bakje) are also reported. 


\section{DISCUSSIONS}

The toponyms reported in ROD 1914 in Magelang cannot be separated from the historical process so as to cause a change in the names of the locations. As stated above, the change of toponym from the Dutch East Indies period until now is not very significant. Tracking the toponym locations mentioned in ROD 1914 can still be done using the current toponyms and old maps published by Topographische Inrichting. This condition certainly facilitates the location tracking process. Even so, there are also a number of toponyms that cannot be traced because they are strongly believed to have changed. The changes in the administration system from the Dutch East Indies period to the independence era seem to have an influence on the change in the toponyms. One of them is the administrative changes that took place after the Indonesian Independence. In the Dutch East Indies period, the district administrative unit, which is currently a subdistrict level, amount to seven but then change to 22 subdistricts at this present. Certainly, this expansion of administrative units also occurs at the village or ward level.

The expansion of administrative units will of course also cause a change in name. Despite the change, the toponyms can still be identified for their locations. For example, a change in the name of a village occurs to Candiretno village in which Retno temple site is located. In ROD 1914 and the 1915 map, the name of this village is Tjandiredja (Krom, 1914, pp. 235-236). Another example is the name Gondangan which is now Gondangrejo. In ROD 1914, Gondangan toponym belongs to District Moentilan, while it currently belongs to Dukun Subdistrict. From these two examples, it can be assumed that the toponym that cannot be traced on the Indonesia topographical map or the ancient map may be the name of a location known only by the local community. Therefore, further tracking by exploring in the field need to be performed to find out the existence of the toponym.

In addition to the lack of toponym changes in Magelang, the efforts to trace the existence of Hindu-Buddhist archaeological remains are also supported by the systematic archaeological inventory reports. The descriptions of each archaeological record are sorted by administrative-territorial units, starting from resident, afdeeling, to district. The report began to be arranged systematically when an official archaeological institution was formed by the Dutch East Indies Government in 1901. This institution was originally named Commissie in Nederlandsch-Indië voor Oudheidkundig Onderzoek op Java en Madura or often referred to as Oudheidkundige Commossie (Archaeological Commission) with J.L.A. Brandes as the chairman. The main work was to make an inventory of collections and lost ancient objects in Java. The results were published in a series of reports entitled Rapporten van de Commissie in Nederlandsch-Indië voor Oudheidkundig Onderzoek op Java en Madoera (ROC) from 1901 to 1912. On June 14, 1913, the Oudheidkundige Commissie was officially changed to Oudheidkundige Dienst in Nederlandsch-Indie (Archaeological Service). This institution did not only handle ancient objects from the Hindu-Buddhist era, but also prehistoric and Islamic archaeological objects throughout the Dutch East Indies territory. The archaeological reports from this institution were published in Rapporten van den Oudheidkundigen Dienst in 
Nederlandsch-Indie: Inventaris der Hindoe-oudheden or often referred to as ROD (Degroot, 2009, p. 4).

In the period of 1912 to 1949, another report entitled Oudheidkundig Verslag or known as OV was published. This report is more complete compared to ROC and ROD because it contains a more in-depth description of the excavation and restoration of archaeological remains. OV also contains descriptions of the remains, sketch drawings, and includes photographs of ancient remains. In addition, OV does not only focus on reporting ancient remains on the island of Java but also on the island of Sumatra.

The systematic inventory reports can be prepared more comprehensively after the establishment of government agencies that handle ancient remains independently. These reports can also be printed and published on a broader scale. The widely reported archaeological heritage protection was strengthened by the new regulations issued by the Dutch East Indies government. In 1931, Monumenten Ordonantie number 19 of 1931 (Staatsblad, 1931 Number 238) was issued. This was then updated with Monumenten Ordonantie number 21 of 1934 (Staatsblad, 1934 Number 515).

The inventory reports from the Government of the Dutch East Indies which are already quite systematic can actually be used for various purposes and strategies for the research and preservation. In the field of research, until now, Hindu-Buddhist archaeological research in Magelang has always focused on locations that have large temples, such as Borobudur and Sengi areas although the number reported in ROD 1914 is far greater. The prospect of Hindu-Buddhist archaeology research in Magelang can be opened more broadly and of course, the historiographic and archaeological coherence in the Hindu-Buddhist period in this region will be more organized. Furthermore, the density of Hindu-Buddhist archaeological remains in the form of temple buildings and fragmentary remains can show how the spatial structure and hierarchy of Magelang in the HinduBuddhist period. In addition, the distribution pattern can also indicate the pattern of community settlements at that time.

An interesting research theme that can be developed from the results of this tracking includes temple building materials. Besides the considerable number, the types of temple building materials reported in Magelang are also varied. Some temple buildings are reported to be made of stone (steenen), both processed stone (steenenblokken) and bare stone or river stone (kalisteenen). However, some temple buildings are reported to be made of bricks (baaksteen, baak). This is quite interesting considering that so far brick temple buildings are only found in East Java, Batu Jaya, and Sumatra. Studies on brick temples in Magelang and around Borobudur are already conducted (Tjahjono, 2002a, 2002b, 2003) but they do not explain all brick temples reported by the Dutch.

Concerning the unique types of reported archaeological remains, ROD 1914 on page 236 also mentions a temple building that is quite unique. This site is reported with the name Setan. At present, Setan village belongs to Secang Subdistrict. The location is quite close to Retno Temple. The temple building in Setan is reported to be located in Bandoengan hamlet (in het gehuct Bandoengan). It is a long temple foundation (fundamenten) which has seven rooms lined to the side (zeven tempelkamers naast elkaar). The middle room is the most spacious one (een 
groote in het midden), so it can be described as if the largest room is flanked by each of the three rooms next to it. In this temple building, as many as 14 Ganeça statues (daarbij werden veertien Ganeca's gevonden) were found. Of the 14 statues, 4 statues were taken to the Batavia Museum (waarvan vier opgenomen in het Museum te Batavia) (Krom, 1914, p. 236).

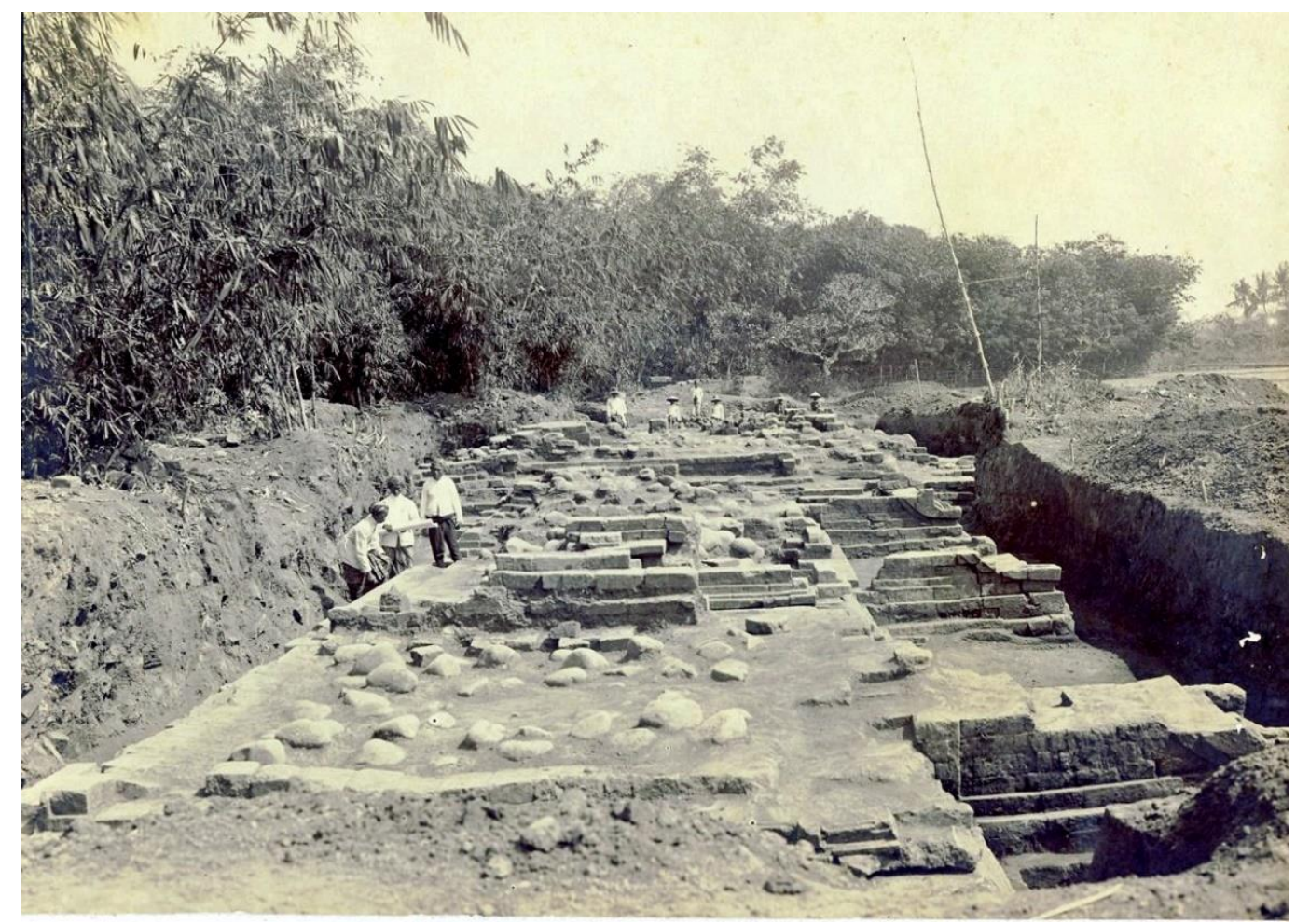

Figure 5. The Excavation of Setan Temple with the photo number OD-1888: Opgegraven fundamenten van Tjandi Setan bij Magelang

(Source: kitlv.nl)

The description of Setan Site can also be found in OV. In OV 1914 pages 56 and 189, it was reported that around 1914, an excavation was done at Setan Temple near Magelang. This excavation found a floor plan of a brick building. Each flanking building has a square floor plan with a side of $4.85 \mathrm{~m}$, a distance between rooms of $1.40 \mathrm{~m}$, and a depth of $1.2 \mathrm{~m}$ below ground level. This brick structure is combined with the composition of river stones on the inside (stuffed stone). From the photo archives, it can be seen that Setan Temple is located on a rice field bordering a bamboo garden, which is likely to have a source of water in both the spring and river. The excavation of the temple is documented in the photo archives of OD-1888 (Figure 5), OD-1889, and OD-1890. The numerous findings of Ganeça statues indicate that this temple is a place for worshipping Ganeça. In 1914, the excavation at Setan Temple is reported to be completed (Oudheidkundig Verslag 1914, 1914, pp. 56-57; 189-190).

The structure of Setan Temple is thought to be buried again after the excavation in 1914, whereas according to Degroot, this temple is lost (Degroot, 2009, p. 44) due to possibly being dismantled like Banon Temple near Borobudur. Until now there is no modern research or literature that discusses more this 
temple. In fact, according to the Dutch East Indies reports, Setan Temple is a very unique temple and is probably the only one in Indonesia, referring to the architectural design and statues. Therefore, an in-depth study is necessary to rediscover this site before it is affected by regional development projects.

ROD 1914 also reported a place of worship in the form of a cave. It is possibly like Sentono Cave found around Abang Temple in Yogyakarta. This cave site is reported as Batoe Rong and located in Paren hamlet precisely between Beser and Tersmi Hills. It is a temple cave (tempelgrot) or hermitage cave with an altar, linga, and yoni in it. This cave is said to have a similar character to Seplawan Cave in Purworejo (Krom, 1913, pp. 156-157). Based on various archaeological studies performed to date, this type of worship place has never been found in the region of Magelang.

In addition to Hindu-Buddhist archaeological remains in the form of temple buildings and ruins, ROD 1914 also reported fragmentary remains. In Java, especially in the regions of Magelang, Kedu, Sleman, and Klaten, remains of worship facilities in the form of statues, linga-yoni, and yoni that is not part of the holy buildings are commonly found. This is usually associated with locations that are considered sacred. Yoni is even often found without linga. The tradition of using yoni without linga illustrates that yoni still has a role as a symbol of fertility (Utomo, 1981). Therefore, in Magelang, many yonis are discovered on agricultural land, either one or two or three yonis in a row. The fragmentary remains, besides standing as the objects of worship, can also be said of being part of a wooden worship building. This is reinforced by the presence of some sites which are reported to contain remains in the form of umpak (oempaks) such as in Tjandi and Goenoeng Gana, both of which belong to District Moentilan.

In the field of preservation, tracking down Hindu-Buddhist archaeological remains from the Dutch East Indies reports can be listed in the priority scale. The data can be used for conservation purposes first, as stated in the Law of the Republic of Indonesia Number 11 of 2010 Concerning Cultural Conservation. This will certainly minimize the loss of data due to the impact of regional development projects. Frequently, stakeholders who have concern and authority over archaeological remains, including the government, academics, and cultural observers always feel cheated when there are discoveries of archaeological objects. Especially when the archaeological discoveries occur in a construction project site as happened at Sekaran Site, Malang Regency during the construction of PandaanMalang toll road Section V in the mid of March 2019 (Yanuar, 2019). Similar events can also occur in Magelang when construction projects are increasingly being performed. For example, Petirtaan Mantingan in July 2019 was discovered by local people when they were making a fish pond (Sugondo, 2019). This site is reported in ROC 1911 on pages 241-243, ROD 1913 on pages 137-138, and ROD 1914 on page 263. In these reports, even the types and number of findings along with records of remains and locations of their removal are mentioned.

Another example can be found at the Liyangan Site, Temanggung Regency, which was first discovered in 2008. This site is the most complete and rarely found settlement site in Indonesia (Tanudirjo, Yuwono, \& Adi, 2019). In ROD 1914 page 294 , this site is reported as Poerbesari. The report mentions the findings of several metal objects in Liangan Hamlet (in het Gehuct Liangan) such as bronze containers 
(bronzen pot) along with fragments that are predicted to be the bottom or lid (fragment van een bodem of deksel), bracelets (armbaden), and some rings (een paar ringen). The findings in the form of bronze containers and fragments were brought to the Batavia Museum, while the bracelets and rings were brought to Leiden (Krom, 1914, p. 294).

Some of the case examples above show that the tracking model of HinduBuddhist archaeological remains in the Dutch Indies reports can help determine the potential of archaeological remains in a region. Furthermore, this potential can be used for future policymaking. The Hindu-Buddhist archaeological research will further develop and, on the other hand, the preservation and utilization of the archaeological remains found will be comprehensive. Borobudur Temple is a concrete example of the archaeological finding which, in the process of research and preservation, always refers to reports from the Dutch East Indies period, even before. Therefore, it is not impossible that this method can also be applied to other Hindu-Buddhist archaeological remains in the region of Magelang.

The tracking model application of the Hindu-Buddhist archaeological remains as reported by the Dutch East Indies Government in Magelang show satisfactory results. The locations in ROD 1914 whose findings are temples amount to 107 locations. The temples can be in the forms of an intact building, an identified basic structure, or ruins. When 109 locations containing fragmentary remains are added, this total number can show the level of density of Hindu-Buddhist archaeological remains in the region of Magelang.

Most of the remains in the form of temple buildings are located in the eastern part of Magelang. The highest density is found around District Grabag, which currently becomes Grabag Subdistrict and Secang Subdistrict, and around District Moentilan, District Salam, and District Salaman. This distribution pattern shows that Hindu-Buddhist sites are mostly found at the foot of Mount Merbabu and in the valley between Progo River and Elo River. These areas currently belong to the Strategic Regional Development of Magelang, Muntilan, and Borobudur which is part of the Yogya - Solo - Semarang - Strategic Regional Development (Ministry of Public Works \& Housing, 2015). Therefore, it is very clear that the level of threat to the preservation of archaeological sites in Magelang is very high. Further efforts need to be made immediately and one of them is to detect archaeological remains as reported by the Dutch East Indies Government.

As a model, of course, it is necessary to apply to regions that are believed to have important positions in the Hindu-Buddhist period, especially Java and Madura which are the focus of the majority of the Indies-Dutch reports. This process must also be followed up by verifying and validating data in the field so that it can provide feedback in making a model that is more accurate and relevant. The cultural characteristics, physical environment, and historical setting of each different region will determine the continued use of toponymy and today's conditions of Hindu-Buddhist archaeological remains. 


\section{CONCLUSIONS}

The inventory reports from the Dutch East Indies period show that Magelang has a very high potential for the existence of Hindu-Buddhist archaeological remains. However, this is not realized in the form of a distribution map so that the data can only be viewed quantitatively. This potential needs to be explored more in-depth using modern methods so that all data previously disclosed by the Dutch East Indies Government can still be utilized for various purposes. The use of toponym and spatial approaches with the GIS device can support representing the distribution map in the reports. The density and distribution pattern of Hindu-Buddhist archaeological remains in the Dutch East Indies period can be more clearly illustrated. This representation can certainly be employed to formulate strategies for future research and conservation. The archaeological remains that have been reported can be lost at any time because there are no follow-up actions such as security and control measures after being reported. Moreover, the fact that there are various projects of regional development that threaten the preservation of Hindu-Buddhist sites in this region.

The toponym analysis model for tracing the existence of Hindu-Buddhist archaeological remains in the Dutch East Indies Archaeological Service report can be tried out in other regions of Java and Madura. These two regions are the focus of several reports issued by the Dutch East Indies Government. Furthermore, the activities of protecting and preserving the locations reported by the Dutch East Indies Government can be performed. The application of the model is not only limited to one report document, but can be developed in similar reports such as OV, ROC, or even the older ones such as TBG (Tijdschrift Bataviaasch Genootschap). Each of these reports can contain different levels of information and region coverage so a comparison is needed in the tracking process. Thus, all reported archaeological remains can be followed up at the present time to accommodate various interests in the future.

\section{ACKNOWLEDGEMENTS}

I would like to express my sincere gratitude to Dr. Daud Aris Tanudirjo, M.A. and Drs. JSE Yuwono, M.Sc. for their help, suggestions, and discussion for the completion of this study. 


\section{BIBLIOGRAPHY}

Adi, A. M. W. (2012). Distribusi Situs Klasik di Wilayah Barat Gunung Merbabu: Kajian Analisis Lokasional. Universitas Gadjah Mada.

Adi, A. M. W. (2016). Penerapan Analisis Predictive Modelling dalam Rangka Pelindungan Tinggalan Arkeologi Klasik di Kabupaten Magelang. Universitas Gadjah Mada.

Atmosudiro, S. (Ed.). (2001). Jawa Tengah: Sebuah Potret Warisan Budaya. Klaten: SPSP Jawa Tengah.

Cœdès, G. (1968). The Indianized States of Southeast Asia. (W. F. Vella, Ed.). Canberra: Australian National University Press.

Darmosoetopo, R. (2003). Sima dan Bangunan Keagamaan di Jawa Abad IX-X TU. Yogyakarta: Prana Pena.

Degroot, V. (2009). Candi Space and Landscape: A Study on the Distribution, Orientation and Spatial Organization of Central Javanese Temple Remains. Leiden: Leiden University.

Degroot, V., \& Klokke, M. J. (2010). Interrelationships Among Central Javanese Temples: The Example of Asu, Lumbung and Pendem. Archipel, 80, pp. 4575. https://doi.org/10.3406/arch.2010.4176

Fitriana, I. (2015). Penemuan Candi Menunjukkan Kampung Ini Dahulu Daerah Subur. Retrieved 3 August 2019, from https:/ / regional.kompas.com/read/2015/01/20/18185931/Penemuan.Can di.Menunjukkan.Kampung.Ini.Dahulu.Daerah.Subur.

Groot, H. (2009). Van Batavia naar Weltevreden: Het Bataviaasch Genootschap van Kunsten en Wetenschappen 1778-1867. Leiden: Koninklijk Instituut voor Taal-, Land- en Volkenkunde.

Hägerdal, H. (2016). Trajectories of the early-modern kingdoms in eastern Indonesia: Comparative perspectives. HumaNetten. https://doi.org/10.15626/hn.20163704

Hartono, P. (2013). Penemuan Benda Purbakala di Mata Air Hebohkan Warga. Retrieved 3 August 2019, from https://news.okezone.com/read/2013/04/10/513/789416/penemuanbenda-purbakala-di-mata-air-hebohkan-warga

Kementerian PUPR. (2015). Executive Summary: Rencana Pengembangan Kawasan Magelang-Muntilan-Borobudur. Jakarta.

Knebbel, J. (1911). Beschrijving der Hindoe-oudheden in de residentie Kedoe. In Rapporten van den Commissie in Nederlandsch-Indie vor Oudheidkundig Onderzoek op Java en Madoera 1911. Batavia: Albrecht en co./'s-Gravenhage. 
Krom, N. J. (1913). Rapporten van den Oudheidkundigen Dienst in Nederlandsch-Indie 1913. Batavia: Albrecht en co./'s-Gravenhage.

Krom, N. J. (1914). Rapporten van den Oudheidkundigen Dienst in Nederlandsch-Indie 1914. Batavia: Albrecht en co./'s-Gravenhage.

Kusen. (1991). Identifikasi Toponim dalam Prasasti Jawa Kuna Abad IX-X dari Prambanan dan Sekitarnya Dengan Toponim Masa Kini. Yogyakarta.

Mashadi, I., \& Zuharnen. (2014). Kajian Keterkaitan Toponim Terhadap Fenomena Geografis: Studi Kasus Toponim Desa di Sebagian Kabupaten Batang. Jurnal Bumi Indonesia, 3(4).

Munandar, A. A. (2016). Toponimi dalam Kajian Arkeologi. In S. Munawarah (Ed.), Proceedings Seminar Nasional Toponimi (pp. 1-26). Jakarta: Universitas Indonesia.

Murtianto, E., \& Arifin, M. B. (1999). Penyelidikan Potensi Cekungan Bawah Tanah Magelang-Temanggung, Jawa Tengah. Bandung: Direktorat Geologi Tata Lingkungan.

Noerwidi, S. (2007). Melacak Jejak Awal Indianisasi di Pantai Utara Jawa Tengah. Berkala Arkeologi, XXVII(2).

Oudheidkundig Verslag 1914. (1914). Batavia.

Purnama, B. E. (2016). Situs Tamansari di Kalibening Diduga Berasal dari Dinasti Medhang Metriam. Retrieved 11 December 2019, from https://mediaindonesia.com/read/detail/49138-situs-tamansari-dikalibening-diduga-berasal-dari-dinasti-medhang-metriam

Ramadhan, A. (2017). Peneliti Kembali Temukan Reruntuhan Candi Peninggalan Mataram Kuno di Magelang. Retrieved 11 December 2019, from https://jogja.tribunnews.com/2017/01/19/peneliti-kembali-temukanreruntuhan-candi-peninggalan-mataram-kuno-di-magelang

Resiyani, W. (2010). Toponim Masa Kini Berasal dari Sumber Prasasti Abad IX-X Masehi yang Ditemukan di Kabupaten Temanggung, Jawa Tengah. Universitas Gadjah Mada.

Scianna, A., \& Villa, B. (2011). GIS Application in Archaeology. Archaeologia e Calcolatori, 22, pp. 337-363.

Soekmono, R. (2002). Menapak Jejak Arkeologi. (S. Atmosudiro \& D. Nugrahani, Ed.). Jakarta: MU:3 Books.

Sugondo, S. (2019). Ditemukan Situs yang Diduga Sebagai Candi Mantingan di Desa Mantingan, Magelang. Retrieved 20 September 2019, from https://jogjainside.com/ditemukan-situs-yang-diduga-sebagai-candimantingan-di-desa-mantingan-magelang/ 
Susanto, E. (2019). Ekskavasi di Magelang Temukan Candi Petirtaan Terbesar seJateng. Retrieved 3 August 2019, from https://news.detik.com/berita-jawatengah/d-4649563/ekskavasi-di-magelang-temukan-candi-petirtaanterbesar-se-jateng

Tanudirjo, D. A., Yuwono, J. S. E., \& Adi, A. M. W. (2019). Lanskap Spiritual Situs Liyangan. Berkala Arkeologi, 9(2), pp. 97-120. https://doi.org/https://doi.org/10.30883/jba.v39i2.474

Tichelman, F., \& Tichelman, F. (2011). Indianized Southeast Asia: Similarities and Differences. In The Social Evolution of Indonesia. https://doi.org/10.1007/97894-009-8896-5_5

Tjahjono, B. D. (2000). Budaya Marginal Masa Klasik di Jawa Tengah. Berita Penelitian Arkeologi, 12.

Tjahjono, B. D. (2002a). Latar Belakang Pendirian Candi Bata di Jawa Tengah. Yogyakarta.

Tjahjono, B. D. (2002b). Persebaran Candi Bata di Sekitar Borobudur. In Kumpulan Makalah Pertemuan Ilmiah Arkeologi ke-IX, Kediri 23-28 Juli 2002. Kediri: Ikatan Ahli Arkeologi Indonesia.

Tjahjono, B. D. (2003). Harta Karun Itu Candi Bata Yang Unik. Berkala Arkeologi, $\operatorname{XXIII(2).~}$

Utomo, B. B. (1981). Persebaran Yoni di Kedu. Universitas Indonesia.

Verhagen, J. W. H. P. (2007). Case Studies in Archaeological Predictive Modelling. Leiden University Press, Leiden. https:// doi.org/10.5117/9789087280079

Wheatley, D., \& Gillings, M. (2010). Spatial Technology and Archaeology. Spatial Technology and Archaeology. London \& New York: Taylor \& Francis. https://doi.org/10.4324/9780203302392

Winata, A. (2018). Analisis Keruangan Perkembangan Ekonomi Wilayah di Kabupaten Magelang Tahun 2010-2014. Universitas Muhammadiyah Surakarta.

Yanuar, Y. (2019, Maret). Candi di Jalan Tol Malang, Arkeolog: Proyek Jalan, Situs Lestari. tempo.co.

Yuliyanto, \& Sudibyakto. (2012). Kajian Dampak Variabilitas Curah Hujan Terhadap Produktivitas Padi Sawah Tadah Hujan di Kabupaten Magelang. Jurnal Bumi Indonesia, 1(1).

Yuwono, J. S. E. (2007). Kontribusi Aplikasi Sistem Informasi Geografis (SIG) in Berbagai Skala Kajian Arkeologi Lansekap. Berkala Arkeologi, 2, pp. 1-14. 